\title{
CONTRASTING INTRANSITIVE MOTION IN ENGLISH AND SERBIAN: HOW DO WE BUILD 'SOUND' EVENTS?
}

\author{
UDC 811.111'367.625 \\ $811.163 .41 ' 367.625$
}

\begin{abstract}
Nataša Milivojević
University of Novi Sad, Faculty of Philosophy, Department of English, Novi Sad, Serbia
\end{abstract}

\begin{abstract}
The paper addresses intransitive motion constructions in English and Serbian with the initial aim of identifying and explaining the structural (construction) templates, which are available in the two languages for intransitive motion encoding. The analysis is based on the well-known proposal by Leonard Talmy $(1975,1985,1991,2000)$ that languages fall into two main types as to how they encode motion events. Special attention is devoted to English and Serbian verbs of emission (VE) (specifically verbs of sound and verbs of light emission), regarding their potential to surface as verbs of motion and combine with directional phrases within motion event constructions.

The analysis aims at contrasting both verbal sub-subclasses in English and Serbian for the purpose of identifying the relevant points of similarities and divergences between the two language systems being analysed. The theoretical claims of the analysis are empirically supported by a contrastive sentential corpus which further promotes the claim that the potential of VE is wider in scope than was initially proposed by Levin (1993).
\end{abstract}

Key words: intransitive motion, verbs of sound emission, verbs of light emission, path of motion, satellite framed languages.

\section{INTRODUCTION}

The paper discusses principles that govern variations in verb meaning in different natural language systems, focusing particularly on those aspects of such meaning which are relevant to encoding motion events and spatial relations. We present a case study in lexical semantic analysis which is focused on a specific set of verbs (Levin 1993) and which is augmented by the syntactic tools dominantly used in the theoretical framework of Construction Grammar (Goldberg, 1995). We analyse two related semantic verb subclasses in the contrastive perspective, namely Verbs of Sound Emission (VSE) and Verbs of Light Emission (VLE) in English and Serbian. These two sub-sets of a larger set of

Submitted July $10^{\text {th }} 2016$, accepted for publication November $7^{\text {th }}, 2016$

Corresponding author: Nataša Milivojević

University of Novi Sad, Faculty of Philosophy, Department of English, Novi Sad, Serbia

E-mail: natasa.milivojevic@ff.uns.ac.rs 
Verbs of Emission (VE) are analyzed in pre-defined structural contexts, within intransitive motion constructions ${ }^{1}$, where they surface as construction heads (or as governing predicators) and receive motion interpretation. The analysis has the following aims and scope:

a) to both theoretically and empirically address the hypothesis of the existence of semantically coherent verb classes in the constrastive perspective;

b) to explore the lexical-semantic and syntactic potential of VSE and VLE to express intransitive motion, given that a motion component is not by definition part of lexical specification of these verbs;

c) to establish and describe contrastive variations of structure associated with intransitive motion in the two languages being analysed as a potential base for a more general parametrization of English and Serbian in natural language typologies, such as Talmy's typology.

The presented theoretical analysis is based on a contrastive sentential corpus which contains three hundred twenty (320) examples of English and Serbian contextual equivalents. $^{23}$ The corpus consists of examples taken from literary sources as well as sentences extracted from various online corpora. The hybrid structure of the corpus serves to illustrate constructional tendencies for encoding intransitive motion in both languages with as little specific limitation to corpus language sample(s) as possible. ${ }^{4}$ The brief representation of the corpus is given in Table 1:

Table 1

\begin{tabular}{lcc}
\hline & \multicolumn{2}{c}{320 sentences } \\
\cline { 2 - 3 } & $\begin{array}{c}\text { Printed sources } \\
\text { (number of examples) }\end{array}$ & $\begin{array}{c}\text { Online Sources } \\
\text { (number of examples) }\end{array}$ \\
\hline VLE (English) & 25 & 35 \\
VLE (Serbian) & 30 & 30 \\
VSE (English) & 50 & 50 \\
VSE (Serbian) & 50 & 50 \\
\hline
\end{tabular}

The paper is structured as follows: a short introduction in section (1) is followed by a theoretical account of the analysis in section (2); section (3) offers a theoretical linguistic explanation of verb event structure; section (4) deals with English and Serbian in contrast; the paper ends with a short section (5), which summarizes the results of the analysis and offers concluding remarks.

\footnotetext{
${ }^{1}$ We adopt the view of intransitive motion proposed by Goldberg (1995): these are constructions headed by intransitive verbs, where no external cause of the motion is presented, as in the example The bottle floated into the cave.

${ }^{2}$ The complete list of sources is avalilable in the end, preceeding the REFRENCE section.

${ }^{3}$ The sentences were chosen as contextalizations of the relevant verb lexemes from both classes in English and in Serbian (the original English verb lexemes based on Levin's classes were initially checked in the available lexicographic sources for Serbian and on the semantic web Wordnet for English).

${ }^{4}$ The empiracla data illustrates a wide variety of language use in both English and Serbian, ranging from colloquial 'everyday' language to written literary style.
} 


\section{THEORETICAL BACKGROUND OF THE ANALYSIS}

One of the striking theoretical presuppositions about the organization of the lexicon is the existence of semantically coherent verb classes which are based on lexical specifications and argument structure templates of the individual verb class members. Many aspects of verbal behaviour including the syntactic expression of its arguments, appear to be determined by such class membership "which often receives a fine-grained semantic characterization." (Levin and Rappaport Hovav, 1997, 489). What is more, the relationship between lexical semantics and syntax has also received substantial attention in the context of the Unaccusative Hypothesis (UH), introduced by Perlmutter (1978). The UH promotes a theoretical view in which intransitive verbs fall into two separate sub-classes, namely unergative and unaccusative, while the two subclasses are associated with two distinct syntactic configurations. The central idea promoted by Perlmutter's proposal is that the subject of the unaccusative verb is a derived subject, being a direct object at some underlying level of syntactic representation, while the subject of an unergative verb is the subject at all levels of syntactic representation. In English, due to independent grammatical rules, the single argument of an unaccusative verb as a rule surfaces as a subject. The syntactic templates which are associated with the two distinct types of intransitive verbs are given in (1):

a. Unaccusative Verb: __ [vp V NP]

b. Unergative Verb: NP [vp V]

The starting point for the present analysis is Beth Levin's study English Verb Classes and Alternations: A Preliminary Investigation (1993). According to Levin's analysis, VSE and VLE are two distinct verb subsets with a somewhat related semantic and syntactic potential. ${ }^{5}$ While VSE dominantly lexicalize emission and production of sound, VLE denote the emission of light. Some typical members of VSE class in English are verbs like babble, whistle and rumble, while typical representatives of English VLE are verbs like blaze, glitter and shine. ${ }^{6}$ What is relevant in light of our analysis is that lexicalsyntactic description according to Levin's original proposal includes a possible motion interpretation for VSE but not for VLE in English. Levin lists the following examples and structural constraints for VSE:

(2) Directional Phrase

The cart rumbled down the street. (Levin 1993:235)

The English example in (2) illustrates a prototypical instance of an intransitive motion construction headed by a VSE rumble, where the attributed motion interpretation is available due to the presence of a directional phrase down the street ${ }^{7}$. Levin proposes that this kind of motion meaning is available only within syntactic unaccusatives such as the example (2), where the sound is a direct consequence of motion (what is more, the motion causes the sound), and where the external argument to the VSE is at the same time the "undergoer" of motion. Levin also points out that unergatives such as

(3) * Shelley whistled down the street.

\footnotetext{
${ }^{5}$ For an extensive discussion see Levin (1993:233-238).

${ }^{6}$ For an elaborate description of VSE in Serbian see Milivojević 2011, 2016a, 2016 b.

${ }^{7}$ In contrast, the following "stative" interpretation of the same example is not acceptable in English:*The cart rumbled.
} 
where the external argument to the VSE is the sound emitter (the sound is emitted from the human vocal tract) and a real syntactic subject as well as a semantic agent are not available in English with dual motion interpretation: in other words, the example is not gramatically available with the interpretation which would allow Shelley and her whistling to move down the street simultaneously ${ }^{8}$.

When it comes to VLE, Levin does not make any account of the possibility of intransitive motion encoding, nor is this mentioned within the available argument structure templates for this verb sub-class.

However, the contrastive empirical evidence from the corpus that was gathered for the purposes of the present analysis will show that the syntactic potential for both VSE and VLE class is 'stronger' and more flexible than what is defined within Levin's proposal; what is more, contrastive evidence will be presented that Serbian exhibits a similar kind of morphosyntactic potential for motion expression with both verb groups. We shall start from the following introductory contrastive examples ${ }^{9}$ :

(4) a. The truck rumbled down the street.

b. Kamion je protutnjao ulicom.

truck is rumbled down the street

(5) a. The bullet whistled through the window.

b. Metak je prozviždao kroz prozor. bullet is whistked through the window

(6) a. The firefly sparkled across the field.

b. Svitac je prosvetlucao poljem.

firefly is sparkeld ascross the field

(7) a. The lightning flashed across the sky.

b. Munja je sevnula preko neba.

lightning is flashed across the sky

As contrastive English and Serbian examples (4-7) illustrate, both English and Serbian express intransitive motion in a similar way: motion interpretation is available provided that a directional argument which expresses the path of motion is present in the construction; what is more, VLE can express motion in the same way as VSE can in both languages. The prototypical syntactic structure of the intransitive motion construction in Englsih and Serbian is given in (8):

$$
\text { a. } \mathrm{VE}_{\text {head }}+\text { Directional phrase } \text { satellite }^{10} \rightarrow \mathrm{IM}_{\text {Constr. }}
$$

According to the natural language typology initially devised by Leonard Talmy (1975, 1985, 1991, 2000), English and Serbian belong to satellite-framed languages. Talmy proposes that languages fall into two main types on the basis of where the path of motion is represented in a sentence expressing a motion event -- or, more generally, where the core schema is represented in a sentence expressing a macro-event (allowing for it to consist of at least two

\footnotetext{
${ }^{8}$ We will show that such interpretations are available in Serbian, which formulates a structural contrast with Englsih.

${ }^{9}$ The analysis presented in the paper is based on a contrastive sentential coprpus which was introduced in the previous section of the paper; also, same examples were taken from the relevant literature and a number of original examples in both languages were devised for discussion purposes. All examples which are not included in the corpus were checked for validity by native speakers of Englsih and Serbian.

${ }^{10}$ Both Englsih and Serbian are dominantly satellite framed langauges according to Talmy (2000).
} 
"micro events" or subevents ${ }^{11}$ ). Talmy discusses lexicalization patterns of a language for certain types of semantic coding. The term lexicalization pattern refers to a generalization concerning the types of meaning that can be associated with specific verb types in a language. Natural languages express or lexicalize different aspects of motion events via different sets of systematic, pre-defined, language-specific patterns or structural templates. Focusing on the motion event itself, the aspects or components which are relevant for its linguistic coding are (1) the (abstract) predicate of motion, (2) the entity which changes its location in space, which is termed as the figure (also theme or trajector in other related approaches), (3) the reference point of the movement, termed as the ground and (4) the path of the motion with respect to the ground. In addition to these frame elements, optional motion event coding factors are (5) the circumstance event of motion, typically the manner, which accompanies the motion i.e. running, rolling or floating, and (6) the event initiating or originating the motion, or the causation event. According to Talmy's original proposal, other satellite-framed languages are for example German and Russian, while typical verb-framed languages include for example French and Spanish. The notion of satellite has been looked at differently in various frameworks; for the purposes of this analysis, we will adopt a definition of satellite element in the construction proposed by William Croft (Croft et al. 2010: 207):

Anything that is not a verb root but encodes an event component will be analysed as a satellite. This definition therefore includes English prepositions which encode the framing/result subevent, even if they do not occur without an accompanying ground expression. Beavers (2008:286, fn 3) gives the same analysis of satellites for the same reasons as those given above.

This definition of the notion of satellite places Serbian prefixes into the Serbian satellite morphosyntactic inventory, along with prepositions case inflections, while in English satellites mostly include prepositions, and verb particles. ${ }^{12} \mathrm{We}$ will conclude this section with a brief observation that the natural language typology proposed by Leonard Talmy is essentially constructional, since it proposes language pre-set structural templates for motion encoding as the basis for language classification. This is closely aligned with the notion of construction in traditional Construction Grammar (Goldberg 1995, Croft et al. 2010) where constructions are viewed as systematic pairings of meaning and structure, or as Croft (Croft et al 2010: 234) explains:

The value of ... typological classification is that there are patterns in the complex event types encoded by different constructional types in Talmy's typological classification. One can define a morphosyntactic scale of the different constructions in the Talmy classification; the morphosyntactic scale is paralleled by a semantic or conceptual scale of how typically or naturally the subevents of the complex event go together. Finally, there is evidence that the different types in the Talmy classification can be placed into two more or less parallel grammaticalization paths that end with the univerbation of the event and frame expressions in a single morphologically bound predicate form.

\footnotetext{
${ }^{11}$ For a more extensive discussion on event structure see Pustejovsky 1991, Rothstein 2004, etc.

${ }^{12}$ For a more extensive discussion see Milivojević 2016a, 2016b.
} 


\section{The MAIN IngREDIENTS OF VERB EVEnT STRUCTURE}

As was pointed out in the previous section of the paper, the projectionalist taxonomy of Beth Levin (1993) is far from complete when it comes to the class of verbs of emission (VE). The study also does not discuss the full distributional range of these verbs. That is why we will claim here that these verbs display a much richer variety of argument and event structure templates than is originally proposed by Levin. Neither the resultative (as a separate type of the construction) nor the intransitive motion construction of this verb class is listed as a primary relevant argument structure template in Levin's book. Although intransitive motion is usually not treated as a telic construction in the literature, our claim is that all intransitive motion constructions are resultatives (see for example Tortora 1998, Milivojević 2016b). The reasons for this claim are both semantic and structural in nature: semantically, the change of location is treated as a resulting subevent in the event structure; syntactically, both Serbian and English satellites introduce the notion of result structurally, on the level of the construction (Arsenijević 2007, Novakov 2005).

The resultative configuration has received the attention of linguists and scholars working within various theoretical frameworks such as formal, functional, and also a number of constructionist approaches to language. According to Goldberg (1995), the resultative construction displays the semantics X CAUSES Y TO BECOME Z, where Z denotes the result argument which may be realized either by an adjective phrase (AP) or by a prepositional phrase (PP). Goldberg (1995) also claims that this construction is characterized by the following properties:

A. the subject argument has to be an animate agent

B. the object argument has to be patient (undergoes the change of state)

C. the verb has to encode direct causation

D. the resultative adjective has to designate the endpoint of a scale (path)

E. the resultative adjective cannot be deverbal.

As will be shown in section 4, only some of these features prove to hold in a cross-linguistic perspective within our account. Namely, the animacy condition will be modified into a teleological capability in line with the proposal of Folli and Harley (2007), while adjectival resultatives will be viewed as a systematic constructional variation between English and Serbian.

Verbs of emission are typically activities with a homogenous temporal structure and a general event template [X ACT <MANNER> ], since they lexicalize the manner of motion. This event template can be augmented into an achievement or accomplishment template once the verb semantics is merged with the construction:

A. Achievements

[BECOME $[\mathrm{X}<\mathrm{STATE}>]]$

B. Accomplishments

[[X ACT <MANNER> ]

CAUSE [BECOME [ Y $<$ STATE $>]]]$

[ X CAUSE [BECOME [ Y <STATE $>]]]$

This description then yields the following canonical realization rule:

Manner verbs VE (they are activities):

[X ACT <MANNER> ]

rumble, creak, whistle

--become resultative intransitive motion templates. 
We, therefore, conclude that event structure templates may be freely augmented up to other possible templates in the basic inventory of event structure templates. However each subevent in the event structure must be identified by a lexical head (e.g., a V, an A, or a $\mathrm{P}$ ) in the syntax (this is typically a satellite element lexicalizing the path of motion). Finally, each argument XP in the syntax must be associated with an identified subevent in the event structure.

\section{ENGLISH AND SERBIAN IN CONTRAST}

Let us at this point go back to the list of examples $(4-7)$ which was discussed in section 2. What is interesting about these sentences is that the verbs surfacing as verbs of motion are in fact verbs of sound and light emission. We look here at the emission verb class as it is outlined in Levin (1993: 233-238) and at their Serbian (lexical) equivalents. Verbs of sound emission (VSE) are a subset of verbs of a larger class of emission verbs along with verbs of light, smell, and substance emission. They describe either the emission or production of sound. They are differentiated from each other by the physical properties of the sound that they lexicalize as well as by the sound's manner of production. Some of these verbs also figure among the verbs of manner of speaking, verbs of sounds made by animals or verbs of impact. ${ }^{13}$ They are generally intransitive, but may sometimes appear with an object (especially with cognates), and they allow for a limited range of external arguments to the verb.

As was already pointed out, VSE in English may become verbs of directed motion within intransitive motion resultatives; in such cases, they require a directional phrase as a complement, be it a directional phrase PP or some other XP with a directional interpretation. In this use, they describe the motion of an entity, characterized by the concomitant emission of the sound whose nature is lexicalized in the verb. Contrary to Levin (1993: 234, 236, 237), we claim that other verbs of emission other than sound emission may appear with directional phrases in English:

(9) a. The elevator whizzed upward.

b. The light flashed into the sky.

b. The firefly flickered into the room

What is more, we claim that there is more freedom along a "structural continuum" of motion expression than is initially proposed in Levin's projectionalist approach. The same kind of construction variety is present in Serbian as well (Milivojević 2011, 2016b):

(10) a. Svitac je svetlucao preko polja. the firefly is sparkled across the field

b. Voda je izbijala ispod belog kamena. water is beat.out under white stone

This kind of explanation also offers initial empirical evidence against some constructional approaches (see Goldberg \& Jackendoff 2004, Jackendoff 2005 among others) where it is

\footnotetext{
${ }^{13}$ This meaning of verbs of sound is especially interesting with bounded PP combined with semelfactive verbs; in those cases, the sound denotation may be backgrounded or weakened completely (see Arsenijević\&Milivojević 2009 for a more detailed discussion).
} 
claimed that directed motion constructions with (sound) emission verbs are "English specific", also ruling out this type of formal structure with any other emission-type verb.

Another generalization we propose as an update on Levin 1993, is that the agents of such verbs must be teleologically capable (Folli \& Harley 2007) of the relevant sound production, rather than simply animate or volitional. ${ }^{14}$

As further empirical illustration of our theoretical claims, the following English and Serbian examples were taken from English and Serbian online corpora, namely The British National Corpus (BNC) (available at http://corpus.byu.edu/bnc/ in (11) and the The Corpus of Contemporary Serbian (available at http://www.korpus.matf.bg.ac.yu/korpus/login.php) in (12):

(11) a. As the tramcars rattled, roared and clanged along Norfolk Street, 60 yards or so from our tenement building, and horse-driven carts rumbled by, the kids of the street were playing, shouting, yelling --; or wiping snotters away with the sweat. It was after school, 4.30 on a nice afternoon...

b. Outside, the rain gurgled in shining gutters.

c. Thick, black rain clouds massed in the sky and, as I fell asleep, rattling raindrops pattered against the wooden shutters.

d. A nurse rustled into the tiny space. Kate could smell Pears soap and the smell brought back memories of when she had been younger.

(12) a. ...pajtaš iz Italije, prešao pešaka granicu . Ja to nisam znala , odradim lepo svoj posao, a njega zatvore. Sledeći dan škripe kočnice iza ćoška, Giška izleće iz kola i pravo pred mene ...

the breaks squeal around the corner ${ }^{15}$

b. Dok automobil stenje u krivinama koje su toliko spiralne da se čak ne bi mogle uporediti ni sa zavrtnjem, kroz maglu koja dočarava visoke planinske vrhove... the car is moaning through the twisting road

c. Nes je to primio kao još jedan dobar znak. Slušao je trenutak, dva, kako voda pršti po kadi, a onda je obukao čistu belu košulju i izvadio novac koji je iz pretinca u kolima prebacio u jedan od svojih kofera... water is splashing around the tub

d. Za to vreme voz je, dahćući, puštajući naglo paru, kloparao visokim nasipom između požutelih kukuruznih polja, između retkih riđih šuma, između talasastih livada...

the train was rumbling up the high slope

Verbs of light emission (VLE), on the other hand, relate to the emission of light, where some of them (both in English and in Serbian) allow for a transitive use with a causative interpretation, as well as locative alternations. ${ }^{1617} \mathrm{We}$ also shall claim here that they may denote either metaphorical or real motion (possibly also in combination with directional prepositional phrases to denote pure light emission along a projected scale) both in English (examples are given in 13) and in Serbian (examples are given in 14). The examples below were also extracted from the online corpora:

\footnotetext{
${ }^{14}$ The notion of teleology in Serbian and other Slavic will not be explored in detail in this paper as it falls out of the frame of the analzsis.

${ }^{15}$ Due to the length of corpus examples, only the intrasnitive motiion cosntruction is glossed.

${ }^{16}$ The stagehand flashed the lights. (Levin 1993: 234)

${ }^{17}$ Jewels sparkeld on the crown./The crown sparkled with jewles. (Lecin 1993: 234)
} 
(13) a. If we could have beamed her down like in Star Trek, it would have been all right, but she just couldn't cope with getting on a plane or a boat.

b. With binoculars the chances are obviously much less, but one never knows --; and it is true that in 1885 a supernova blazed out in the Andromeda Spiral and almost reached naked-eye visibility.

c. The mass of new, hot rock forcing its way up through the crater floor had both helped to displace the water from the crater, and heated it up to nearly boiling point, so it was a scalding torrent that flashed down the valley, travelling at a speed of something like ninety kilometres an hour.

d. His double-headed axe flickered in his powerful hands, light as a birch twig.

(14) a. A nad okeanom, nebom treperi, i onih dana prepunih sunca, neka snena izmaglica, kao prozirni plašt pare.

the mist is shimmering across the sky

b. Pođe, pođe, dođe na mesto gde se skreće lepotici. Skrenu. Dođe pred brvnaru. A u brvnari gori veliki oganj i svetli kroz prozore. the fire is blazing through the windows

The following Serbian example, taken from the literary part of the corpus also are also illustrates the case in point:

(15) U virovima, kroz iskričave proboje sunca, sevale su pastrmke kao kame. (Lov na tigrove) trouts were glittering like sabres in the creeks

What English VLE examples in (13) show is that light emission verbs can, in fact, surface in constructions where they denote intransitive motion, as in (13a) and (13c), or metaphorical motion meaning as in (13b), and finally something like implied movement (either momentary or iterative) as in (13d). Serbian examples in (14) illustrate the fact that VLE behave similarly to English VLE verbs, allowing for the similar range of motion meanings: implied movement accompanied by light reflection in $7 \mathrm{c}$ and light emission along the projected path in $7 \mathrm{~b}$. The example (15) is more "motion-like", combining the verb with a PP denoting direction of light emission.

What can be concluded from the discussion and the examples so far is that Serbian exhibits a kind of morphosyntactic potential in expressing motion events which is similar to English. Both verb classes examined so far, namely VSE and VLE, in English and in Serbian will surface in intransitive motion constructions, with the manner co-event on the verb, and the path of motion expressed by the obligatory satellite argument.

In the remainder of the paper, we will illustrate some points of divergence between English and Serbian. Let's take a look at the following set of examples:

(16) a. *Peter yelled down the street.

b. Jovan je vikao niz ulicu. Jovan is yelled down street

c. Metak je prozviždao pored prozora. bullet is whistled.through by window

d. ?Metak je uzviždao kroz prozor. bullet is whistled.in through window (Milivojević 2011) 
While the English sentence in 16 a is ungrammatical ${ }^{18}$, in that there is no available dual motion reading for the VP, the Serbian example is grammatical and fully acceptable. The example $16 \mathrm{~b}$ is, in fact, ambiguous between two readings where in the first one, the emitter of the sound is not moving, while the emitted sound is the theme (or the figure) of motion, while in the second available reading, both the emitter of the sound and the sound produced are moving along the path. This is an interesting instance in terms of event structure, showing that Serbian perhaps exhibits more freedom in intransitive motion event encoding. ${ }^{19}$ Examples $16 \mathrm{c}$ and $16 \mathrm{~d}$ show that Serbian sound emission verbs combine more freely with paths implying unbounded scales, than with those with bounded scales (or goals). Goals-bounded, or telic-bounded, PPs bound the incremental scale of VP (motion or sound emission), hence making the mapping with the other scale (sound emission or motion, respectively) impossible. (Arsenijević \& Milivojević 2009)

The next point in the analysis is illustrated in the following sets of examples:

(17) a. Peter hammered the metal flat.

b. Mary watered the tulips dead.

c. John slammed the door shut.

The sentences in (17) are the instances of the so-called adjectival resultatives (AP resultatives), or secondary resultative predicates. Surprisingly enough, Serbian behaves like a verb-framed language in this respect:

(18) a *Jovan je lupio vrata otvorena. Jovan is slam door open

b. Jovan je zalupio vrata/ vratima. Jovan is slam.to door/ with door

c. Jovan je tresnuo vrata. Jovan is banged door

d. Jovan je zalupio sušalicu. Jovan is banged.down phone

There are no constructional Serbian to English equivalents of AP resultatives - those sentences are ruled out as ungrammatical. In terms of semantics and usage, the lack of AP resultatives in Serbian is compensated by prefixes, that is, again by available satellite class elements.

Gherke (2008) argues that the focus on Talmy's cross-linguistic variation should be "shifted away from the restriction on paths expressed on the verb or elsewhere, to the question whether or not an accomplishment structure of the AP result type can be built relying on the integration of a non-verbal predicate into an activity structure." (Gehrke 2008: 216) Furthermore, Beavers at al. (2009) argue that the observed cross-linguistic variation arises primarily from the interaction of motion-independent morphosyntactic and lexical factors.

\footnotetext{
${ }^{18}$ As was already explained in the previous sections of the paper, this claim for English unergatives with dual motion meaning is based on the relevant lterature; occasional instances of such constructions were found in our corpus (The mocking birds were singing up and down the street), however they are highly infrequent and do not relate to a singular dual motion imterpretation in English; rather, they are ambiguous between dual motion and true unergative interpretation of the construction.

${ }^{19}$ For an extensive discussion on the issue, as well as various motion meanings allowed for in Serbian see Arsenijević\&Milivojević 2009.
} 
Taken together, these factors predict greater variation in the encoding of motion events than most previous work has acknowledged. In particular, they highlight the role of the verb in determining how the major semantic components of an intransitive motion event - path of motion and manner of motion - are described and combined in a single clause on the basis of two interacting morphosyntactic factors. (Beavers at al. 2009: 26)

First, while the verb is one of several lexical categories that can encode either manner or path, it is unique among all categories in being the only obligatory element across all clauses that describe motion (since it heads the VP that forms the nucleus of the clause). Second, the semantic component which is not expressed in the verb, if it is not inferable from context or unimportant and thus omissible, may (or must!) be expressed by some other constituent in the event structure.

\section{CONCLUDING REMARKS}

The contrastive research presented in this paper is an attempt at a somewhat deeper insight into the linguistic nature of a subset of resultatives in English and Serbian, the intransitive motion constructions. The construction which was the focus of the analysis contains a verb of emission (either VSE or VLE) as the VP head, thus making the construction additionally intriguing for linguistic description. The paper explored the components of argument templates and event structure of intransitive motion resultatives, offering a general formal account of semantic readings for the relevant grammatical patterns. The analysis also included contrastive English and Serbian data as the empirical support of the theoretical conclusions promoted in the paper.

Furthermore, we claim here (in line with Beavers at al. and Croft et al, 2010) that Talmy's typology is too unrefined to provide a full picture of the way motion events are expressed across different natural languages and language types. Therefore, the conclusion is that there is a wide variety of encoding possibilities for motion events that do not comfortably fit into a two-way typology, and that instead of speaking of language "types," we should speak of language "tendencies" of exploitation of their morphosyntactic potential for encoding motion in natural languages.

\section{ONLINE SOURCES}

Elektronski korpus Savremenog Srpskog jezika Prirodno-matematičkog fakulteta u Beogradu http://korpus.matf.bg.ac.rs

Corpus of Contemporary American English (COCA) http://corpus.byu.edu/coca/

Britsih National Corpus (BNC) http://www.natcorp.ox.ac.uk/ 10.2.2016.

Wordnet. A Lexical Database for English https://wordnet.princeton.edu/

\section{PRINTED SOURCES}

English Serbian or Croatian Dictionary. Benson, Morton, Beograd: Prosveta. 1988.

English Croatian or Serbian Dictionary (u redakciji Rudolfa Filipovića). Zagreb: Školska knjiga. 1996.

Veliki englesko-hrvatski rječnik. Bujas, Željko. Zagreb: Nakladni zavod Globus. 2005

Pavlović, Živojin. Zid smrti. Beograd: Prosveta. 1985.

Pavlović, Živojin. Zadah tela. Beograd: Beogradski izdavačko-grafički zavod. 1985.

Pavlović, Živojin Raslo mi je badem drvo. Beograd: Narodna knjiga. 1988.

Pavlović, Živojin. Lov na tigrove. Beograd: Prosveta, BIGZ. 1988. 
Pavlović, Živojin. Divlji vetar (1-10). Novi Sad: DP „Znanje“. Beograd: KVIT Podijum. 1993.

Pavlović, Živojin. Azbuka. Novi Sad: Prometej (Biblioteka Moje detinjstvo). 1997.

\section{REFERENCES}

Arsenijević, B., (2006), Inner aspect and telicity: the decompositional and the quantificational nature of eventualities at the syntax-semantics interface. Utrecht: LOT Publications.

Arsenijević, B., (2007), "Slavic verb prefixes are resultative.”, Cahiers Chronos 17, pp. 197-213.

Arsenijević, B. and N. Milivojević, (2009), "Sound emission and directioanl phrases in Serbo-Croatian", Paper presented at SLG 4 \& SinFonIJA II (Sarajevo Linguistic Gathering 4 and SinFonIJA 2 Conference), Sarajevo, $\mathrm{BiH}$.

Beavers, J., B. Levin, S.W. Tham, (2009), “The Typology of Motion Expressions Revisited”, Journal of Linguistics 46. 2, pp. $1-82$

Croft, W. Et al., (2010), "Revising Talmy's typological classification of complex events”, In Boas, H. (ed.) Contrastive construction grammar, Amsterdam: John Benjamins, pp. 201 - 235.

Folli, R., and G. Ramchand, (2005), "Prepositions and Results in Italian and English: an Analysis from Event Decomposition“, In Verkyul, H., van Hout H., and de Swart H. (eds.) Perspectives on Aspect. Dordrecht: Springer, pp. 81-105.

Folli, R., and H. Harley, (2007), "Teleology and Animacy in Extrenal Arguments“, Lingua 118.2, pp. 190-202.

Gehrke, B., (2008), Ps in Motion: On the Semantics and Syntax of P Elements and Motion Events. LOT Dissertation Series 184. Utrecht: LOT Publications.

Goldberg, A., (1995), Constructions: A Construction Grammar Approach to Argument Structure. Chicago: Chicago University Press.

Goldberg, A., and R. Jackendoff, (2004), "The English Resultative as a Family of Constructions“, Language 80.3: pp. 532-568.

Hay, J., and C. Kennedy, B. Levin, (1999), "Scalar Structure Underlies Telicity in Degree Achievements”, In Mathews, T. and D. Strolovitch (eds.) SALT IX.Ithaca: CLC Publications: pp. 127-144.

Jackendoff, R., (2005), Simpler Syntax. Oxford University Press.

Krifka, M. (1998). The origins of telicity. In: Rothstein, S. (ed.) Events and Grammar. Dordrecht: Kluwer, pp. 197-235.

Levin, B., (1993), English Verb Classes and Alternations: A Preliminary Investigation. Chicago and London: The University of Chicago Press.

Levin, B. and M. Rappaport Hovav, (1997), "Lexical Semantics and Syntactic Structure“, In Lappin, S. (ed.) The Handbook of Contemporary Semantic Theory. Oxford: Blackwell Publishers: pp. 487-509.

Levin, B. (2000), "Aspect, Lexical Semantic Properties and Argument Ecpression". Proceedings of the Twenty-Sixth Annual Meeting of the Berkeley Linguistics Society: General Session and Parasession on Aspect, pp. 413-429.

Milivojević, N., (2007), „Telične partikule u engleskom i perfektivni prefiksi u srpskom jeziku - glagolski vid ili tip glagolske situacije?", Godišnjak Filozofskog fakulteta u Novom Sadu, Vol. XXXII: pp. 397- 407.

Milivojević, N., (2011), "Lexical Specification and Argument structure of English and Serbian Sound Emission Verbs". B.A.S. British and American Studies, 17, pp. 235-246.

Milivojević, N., (2016a), "Revisiting verbs of emission: an update on some relevant theoretical accounts of lexical specification and argument structure of emission verbs". Logos\&Littera: A Journal of Interdisciplinary Approaches to text, 3, vol.1, pp. 25-45.

Novakov, P. (2005), Glagolski vid i tip glagolske situacije u engleskom i srpskom jeziku, Novi Sad: Futura publikacije.

Milivojević, N., (2016b), Konstrukcioni idiomi u engleskom i srpskom jeziku. Edisertacija, Knjiga 10. Novi Sad: Filozofski fakultet. http://digitalna.ff.uns.ac.rs/sadrzaj/2016/978-86-6065-384-2

Perlmutter, D. M., (1978), "Impersonal passives and the Unaccusative Hypothessis". Proceedings of the Annual Meeting of the Berkeley Linguistic Society (BLS) 4, pp. 157-189.

Talmy, L., (1975), "Semantics and syntax of motion". In Kimball J. P. (ed.) Syntax and Semantics vol 4. New York: Academic Press, pp.181-238.

Talmy, L., (1985), „Lexicalization patterns: Semantic structure in lexical forms“. In Shopen T. (ed.) Language Typology and Syntactic Description Vol. 3: Grammatical Categories and the Lexicon. New York: Cambridge University Press, pp. 57-149.

Talmy, L., (1991), "Path to realization - via aspect and result". In Proceedings of BLS 17: pp. 480-519.

Talmy, L., (2000), Toward a Cognitive Semantics: Typology and Process in Concept Structuring. Cambridge, MA: MIT Press.

Tortora, C. (1998), "Verbs of Inherently Directed Motion are Compatible with Regulative Phrases", Linguistic Inquiry 29:2, pp. 338-345. 


\section{KONSTRUKCIJE INTRANZITIVNOG KRETANJA U ENGLESKOM I SRPSKOM JEZIKU: KAKO I KADA ZVUK OZNAČAVA KRETANJE?}

Rad se bavi konstrukcijama intranzitivnog kretanja u engleskom i srpskom jeziku sa ciljem da se rasvetli njihova lingvistička priroda $i$ da se formalno opišu obrasci strukture argumenata $i$ strukture događaja ovih konstrukcija u dva posmatrana jezika. U radu se dodatno razmatra značaj i razvoj tipološke klasifikacije jezika prema Lenardu Talmiju (1975,1985,1991,2000), prema kojoj postoje dva osnovna jezička tipa spram toga na koji način jezik enkodira događaj kretanja. Posmatraju se engleski $i$ srpski jezik u kontrastu, pri čemu se posebna pažnja usmerava na konstrukcije intranzitivnog kretanja čiji je upravni element neki od glagola emitovanja, tačnije glagol emitovanja zvuka ili svetlosti.

Analiza pokazuje da iako se spram velikog dela empirijskih podataka može implicitno zaključiti da dva posmatrana jezika pripadaju istom tipu prirodnih jezika, tj. jezicima sa satelitskim situativnim okvirom, srpski jezik ne može izraziti sekundrano-rezultativne konstrukcije sa pridevom, ali iskazuje nešto veći stepen slobode po pitanju sintaksičko-semantičkog potencijala konstrukcije intranzitivnog kretanja sa glagolima emitovanja zvuka i svetlosti. Istraživanje je zasnovano na konstrastivnom rečeničnom korpusu koji dodatno ilustruje i promoviše tvrdnju da je morfo-sintaksički potencijal klase glagola emitovanja širi nego što je to opisano u relevantnoj amglističkoj literaturi.

Ključne reči: intranzitivno kretanje, glagoli emitovanja zvuka, glagoli emitovanja svetlosti, putanja kretanja, jezici sa satelitskim situativnim okvirom 